\begin{tabular}{c} 
Volume and Issues Obtainable at Center for Sustainability Research and Consultancy \\
Journal of Accounting and Finance in Emerging Economies \\
ISSN: 2519-0318 ISSN (E) 2518-8488 \\
Volume 6: Issue 1 March2020 \\
CSRᄃ \\
Journal homepage: www.publishing.globalcsrc.org/jafee \\
\hline
\end{tabular}

\title{
The Importance of Organizational Justice, Appraisal Purposes and Employee Satisfaction in Performance Appraisal System in Academic Sector of Pakistan
}

\author{
${ }^{1}$ Mohammad Hanif Khan, ${ }^{2}$ Altaf Hussain, ${ }^{3}$ Muhammad Asad Khan \\ ${ }^{1}$ Lecturer, Department of Tourism and Hotel Management, University of Malakand, Khyber Pakhtunkhwa, \\ Pakistan: hanifyousafzai@uom.edu.pk \\ ${ }^{2}$ Assistant Professor, Department of Commerce and Management Sciences, University of Malakand, Khyber \\ Pakhtunkhwa, Pakistan: altafhussain@uom.edu.pk \\ ${ }^{3}$ PhD Scholar, Universiti Tun Hussein Onn (UTHM) Malaysia: asadkhanbte06@gmail.com
}

\begin{tabular}{|c|c|}
\hline ARTICLE DETAILS & ABSTRACT \\
\hline $\begin{array}{l}\text { History } \\
\text { Revised format: February } 2020 \\
\text { Available Online: March } 2020\end{array}$ & $\begin{array}{l}\text { The purpose of this article is to find out the importance of organizational } \\
\text { justice and its types along with employee satisfaction in the performance } \\
\text { appraisal system. Data were collected from a sample of } 180 \text { respondents } \\
\text { who replied their opinions regarding the variables included in the study. }\end{array}$ \\
\hline $\begin{array}{l}\text { Keywords } \\
\text { Organizational Justice, Employee } \\
\text { Satisfaction, Performance } \\
\text { Appraisal, Higher Education } \\
\text { Sector }\end{array}$ & $\begin{array}{l}\text { This study used SPSS to analyze collected data. The findings of study } \\
\text { found a linkage of three kinds of organizational justice with performance } \\
\text { appraisal. Also a strong association of employee satisfaction was found } \\
\text { with components of organizational justice. The core restriction is that this } \\
\text { study provides information limited to only one source, i.e. employees. } \\
\text { This paper has practical effects on human resource development as it }\end{array}$ \\
\hline $\begin{array}{l}\text { JEL Classification: } \\
D 23, D 29, I 23\end{array}$ & $\begin{array}{l}\text { gives human resource practitioners and also to managers acting as rater of } \\
\text { their employees with different ideas and recommendations. Such ideas } \\
\text { and recommendations typify how to maximize the perceived justice of the } \\
\text { performance appraisal system in higher education sector of Pakistan. This } \\
\text { study will also add some extra knowledge to the stake holders in higher } \\
\text { education sector to understand and pinpoint the role of performance } \\
\text { appraisal in academic sector. }\end{array}$ \\
\hline
\end{tabular}

(C) 2020 The authors, under a Creative Commons Attribution-Non OPEN ACCESS

Corresponding author's email address: altafhussain@uom.edu.pk

Recommended citation: khan, M. H., Hussain, A. \& Khan, M. A., (2020). The importance of organizational justice, appraisal purposes and employee satisfaction in performance appraisal system in academic sector of Pakistan. Journal of Accounting and Finance in Emerging Economies, 6 (1), 191-200

DOI: $10.26710 /$ jafee.v6i1.1079

\section{Introduction}

Performance appraisal is known as the main component of performance management systems (Gruman \& Saks, 2011). Performance appraisal is a formal and systemic method used to identify measure and improve employee job performance (Prowse \& Prowse, 2010). Shrivastava and Purang (2011) termed performance appraisal as a central technique for every organization. Armstrong and Taylor (2014) suggested the strategic role of performance appraisal and it is blended in the organizational policies and 
actions of human resource. Dissatisfaction and perceptions of unfairness and inequity in appraisal evaluations result into failure of any performance appraisal system (Iqbal, Ahmad, \& Haider, 2013). This research aims to explore facets of performance appraisal which are associated with organizational justice and its three kinds i.e. procedural justice, distributive justice and interactional justice. Especially, perceived purposes of performance appraisal are taken into consideration, method employed and employee satisfaction regarding performance appraisal. In public sector organizations performance appraisal is considered as a feature of "new managerialism"(Peters, 2013). Organizational justice is also one of the important points of concern about performance appraisal system (Thurston Jr \& McNall, 2010). In management literature, studies have revealed that justice perceptions influenced employee's behaviour in the organizations particularly in higher education sector (Elamin \& Alomaim, 2011). Though, there is still disagreement on interactional justice should be perceived as a part of procedural justice or not in the whole organizational justice scenario of an organization (Jawahar, 2007). Employee satisfaction also plays a key role in the success of any performance appraisal system because its acceptance is related with employee level of satisfaction and depends on organizational justice (Jawahar, 2007).

\section{Problem Statement}

Currently public sector universities in Pakistan are not performing well and its performance is alarming and not promising. Faculty members in these universities seems to be non-productive and rarely contribute towards the university performance (Khan, Shamsudin, \& Syed Ismail, 2016; Shan, Ishaq, \& Shaheen, 2015). It is noted with great concern that why the public sector universities are not making place in international ranking and performance. There are so many reasons behind this situation in which lack of organizational justice (Khan et al., 2016), employee satisfaction from appraisal and low job performance were find the most crucial ones and needs to be addressed. This study is conducted to ponder on essential queries regarding organizational justice in public sector universities of KP. It would benefit to inspect the usual influence of organizational justice aspects on employee satisfaction and performance appraisal system (Afridi, 2018). The organizational justice might be one of the leading problems that are not examined thoroughly in the public sector universities of Khyber Pakhtunkhwa to identify its impact on employee satisfaction and performance appraisal.

\section{Research Questions}

- Is administrative purpose have any relationship with distributive and procedural justice

- What is the relationship between developmental purpose and interactional justice

- What is the relationship between employee satisfaction and procedural justice

- Is employee satisfaction have any relationship with interactional justice and organizational justice

\section{Literature Review}

\subsection{Organizational Justice}

Researchers have identified ideas of justice for the last 60 years that how and when organizational justice prevails in workplace (Rowland \& Hall, 2012). Study of fairness at workplace is termed as organizational justice (Palaiologos, Papazekos, \& Panayotopoulou, 2011). In organizational context, for the first time Greenberg (1986) apply organizational justice theory to performance appraisal. The author further elaborate that fairness is being subject to the organization. Three types of justice are of particular interest to human beings as per previous literature. Distributive justice deals with the fair distribution of the outcomes in organization (Al-Zu'bi, 2010). The author further stresses not only on the distribution but also on the perception of the fairness (Chernyak-Hai \& Tziner, 2014). Another researcher like (Gupta \& Kumar, 2012) maintained that employees match their efforts with the performance appraisal rating they obtain and the establishment of the fair ratings in performance appraisal. Some previous researchers identified that employees anticipate ratings leniently in comparison to others (Cardador, 2014). In continuation to the latter one, the procedural justice describes the fairness in procedures about outputs and refers to establish fairness in issues regarding process, techniques and tools used to define those outcomes 
(Palaiologos et al., 2011). Procedural justice relates to the rules and procedures employed to accomplish ends. The last one is interactional justice, which obviously determines that employees perceived fairness in interpersonal dealing and communication that they observed (Fernandes \& Awamleh, 2006). It is significant to highlight that interactional justice get attention on how the employees of the institutions are being treated by their immediate bosses using their authority in making decisions (Fernandes \& Awamleh, 2006).

\subsection{Purposes of Performance Appraisal}

Performance appraisal is used in organizations for carrying out different purposes likewise, to promote employee performance and productivity (Ikramullah, Shah, Khan, Hassan, \& Zaman, 2012), improve employees to develop their abilities and also to improve those weak areas of employees that has negative scores (Katou \& Budhwar, 2010). According to Boswell and Boudreau (2000) postulated that performance appraisal system is meant for administrative purposes i.e. salary, promotion, termination and layoff and also for developmental purposes i.e. training of employees, providing employee with continuous performance feedback and establishing employees strengths and weakness. Boswell and Boudreau (2000) suggested that supervisor or rater assign ratings leniently if it is used for developmental purpose and contrary to this, Cleveland and Murphy (1992) proposed that supervisor or rater assign high ratings for administrative purposes in terms of pay raises, promotion and give low ratings in terms of feedback and development. According to Palaiologos et al. (2011) found that employees believed rater/supervisor were the crucial to the performance appraisal success with focus on accurate ratings, purposes and feedback by supervisors. Wright (2004) opined that employees found performance appraisal to be more effective when they are specific and concentrated, intended and well managed, easy to comprehend and control the process. The success of performance appraisal system may be determined by employee's perception of fairness (Jawahar, 2007). If employee's perceived dissatisfaction, unfairness and inequity in performance assessment then any performance appraisal system will be considered failed (Palaiologos et al., 2011). While, Warokka, Gallato, Thamendren, and Moorthy (2012) argued that the performance appraisal method will cause dissatisfaction if employees perceived it biased, unfair and irrelevant. Shields et al. (2015) stated that performance appraisal is essential to established performance objectives, resolve performance issues and used incentive, selection and termination. Particularly, performance appraisal can also be applied for different purposes such as managing employee performance encompassing setting clear goals, career development compensation and identifying improvement prospects (Shields et al., 2015). According to Youngcourt, Leiva, and Jones (2007) there are two types of purposes namely administrative and developmental. In the administrative purpose supervisor assess the evaluation output and resolve problems such as salary increases and promotions. While on other hand, developmental purpose is meant for emphases both on employee development and competencies and their personal development (Werner \& DeSimone, 2011).

Especially, the administrative purpose of performance appraisal established a linkage between performance appraisal and fairness. These relationship maximize the possibility that performance appraisal is supposed as more unbiased to both method and content. While, developmental purpose objects at individual development, looks more connected to interactional justice based on good interactive relations. Keeping in view previous literature following hypotheses is developed in present study.

H1. The administrative purpose of performance appraisal has a strong relationship with distributive and procedural justice.

H2. The developmental purpose of performance appraisal has a strong relationship with interactional justice. 


\subsection{Employee Satisfaction}

Kehoe and Wright (2013) have affirmed the prominent role of performance appraisal system in the development of employee attitudes and maximize motivation to improve job performance. Employee satisfaction has been considered as to motivate and improve employee job performance with performance appraisal system (Selvarajan \& Cloninger, 2012). According to Gunlu, Aksarayli, and Şahin Perçin (2010) satisfaction is a significant goal for organization to achieve, factors which mostly contribute and relate to employee satisfaction are customer satisfaction, productivity and retention of employees. Those employees which are satisfied hence motivated to produce higher customer satisfaction and ultimately positively affect organizational performance (Bakotić, 2016). In addition, effectiveness of performance appraisal system is dependent on both its methodological aspects and overall administrative design and organizational design. Performance appraisal system is not only used as distributive activity but it also encompasses other organizational activities (Pooyan \& Eberhardt, 1989). Employees' satisfaction has three major components associated with performance appraisal. First component of satisfaction relates with ratings, if they are highly rated in evaluation, it stimulates their positive reactions about performance evaluation (Kacmar, Wayne, \& Wright, 1996). Performance ratings are also considered as an imperative facet of performance appraisal satisfaction according to Bernardin and Wiatrowski (2013), and act as base for several administrative decisions. Higher ratings has been taken by employees is a source of satisfaction in comparison with low ratings. The supervisor or rater has to play a key role to give assurance of positive outcome and provide some distinguished feedback to employees to improve their performance (Palaiologos et al., 2011). According to Kassing (2011) the most critical one is the ratee-rater relationship. Feedback is crucial because of its positive impact on employee's reaction to ratings (De Stobbeleir, Ashford, \& Buyens, 2011). Hence, performance feedback and satisfaction performs a significant role in various administrative activities such training and development, career growth and motivation (Van Dijk \& Kluger, 2011). Keeping in view the aforementioned findings, it is said that employee satisfaction with ratings is related with procedural element of performance appraisal which results into improved procedural justice. And employee satisfaction also exist a positive relationship with overall organizational justice.

H3. Employee satisfaction has a positive and significant relationship with procedural justice H4. Employee satisfaction has a positive and significant relationship with overall organizational justice.

\section{Research Framework}

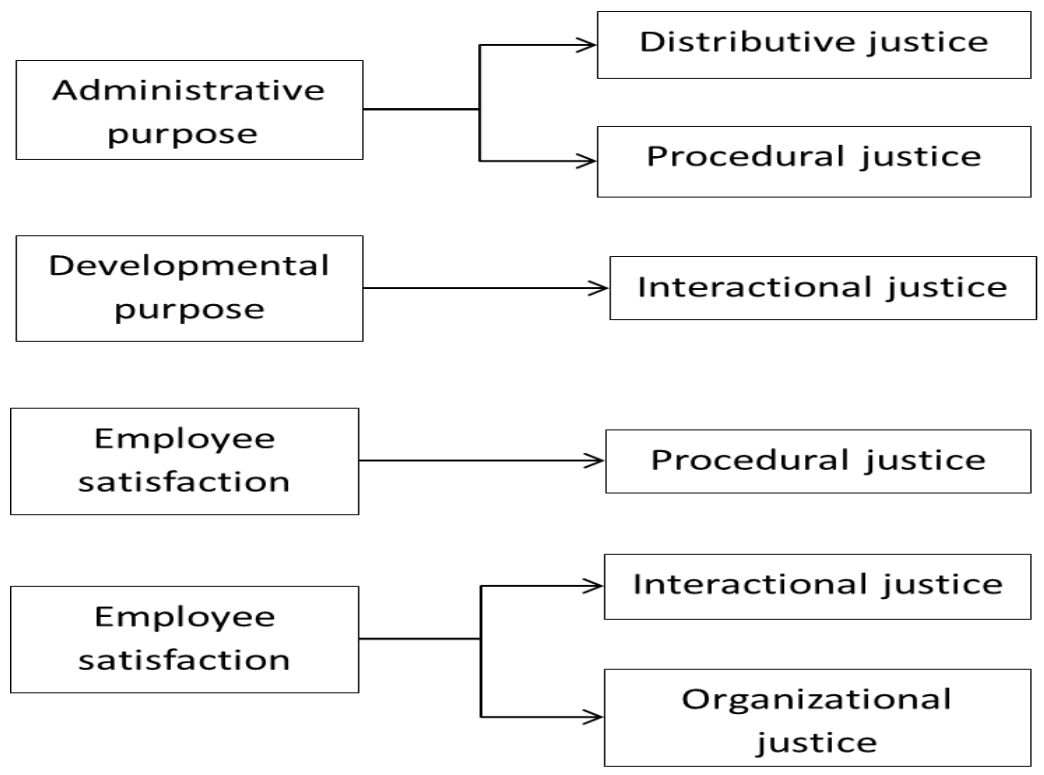

Figure 1: Research Framework of the Study 


\section{Methodology}

The data were collected by using questionnaires that were sending through an email. Respondents were faculty members of public sector universities of Pakistan. The criteria for involving a university or individual faculty member in our sample can be categorized as follows. First the organization or university has a performance appraisal system and prevailing for the last three years. Second the faculty members can answer the questionnaire only if they had been appraised at least one time in the service. The sample of this study comprises of 180 questionnaires, out of these 120 were obtained recording response rate of $66 \%$. Majority faculty members in this study sample are appraised annually and their head of the department/Dean being their supervisor in most of the cases. Our respondents were faculty members of different ranked such as Lecturers, Assistant professors, Associate professors and Professors.

\subsection{Measures}

The questionnaire of this study was designed based on items taken from series of related studies, Jawahar (2007); Kuvaas (2007); Colquitt (2001) and (Youngcourt et al., 2007). The questionnaire contained total of 35 questions (variables of study), in which first part described the purposes of performance appraisal system and second part illustrated demographic information. All questions were measured using 5 points Likert scale. Its descriptive statistics can be seen in Table 1.

Table1: Statistics and Reliability of Variables

\begin{tabular}{|l|l|l|l|l|}
\hline \multirow{2}{*}{$\begin{array}{l}\text { Dependent and } \\
\text { independent variables }\end{array}$} & $\begin{array}{l}\text { Normalized } \\
\text { statistics } \\
\text { divided by no. } \\
\text { of items) }\end{array}$ & $\begin{array}{l}\text { Cronbach's } \\
\text { alpha }\end{array}$ & Number of items \\
\cline { 2 - 3 } & Mean & SD & \\
\hline Administrative purpose & 3.31 & 0.745 & 0.769 & 3 \\
\hline Developmental purpose & 2.26 & 0.878 & 0.748 & 3 \\
\hline Procedural justice & 3.63 & 0.755 & 0.847 & 12 \\
\hline Distributive justice & 2.92 & 0.723 & 0.972 & 5 \\
\hline Interactional justice & 3.42 & 0.982 & 0.942 & 10 \\
\hline Employee satisfaction & 3.75 & 0.805 & 0.912 & 2 \\
\hline
\end{tabular}

\section{Results}

The research paper is aimed to analyze the components performance appraisal which is associated with organizational justice. In a connection to test the model SPSS has been used to run correlation analysis is shown in Table 2.

Table2: Correlation between Variables

\begin{tabular}{|l|l|l|l|l|l|l|}
\hline & 1 & 2 & 3 & 4 & 5 & 6 \\
\hline $\begin{array}{l}\text { Administrative } \\
\text { purpose }\end{array}$ & 1 & & & & & \\
\hline $\begin{array}{l}\text { Developmental } \\
\text { purpose }\end{array}$ & 0.665 & 1 & & & & \\
\hline Procedural justice & 0.552 & 0.545 & 1 & & & \\
\hline Distributive justice & 0.493 & 0.543 & 0.552 & 1 & & \\
\hline Interactional justice & 0.552 & 0.513 & 0.317 & 0.552 & 1 & \\
\hline $\begin{array}{l}\text { Employee } \\
\text { satisfaction }\end{array}$ & 0.443 & 0.382 & 0.221 & 0.365 & 0.596 & 1 \\
\hline
\end{tabular}


The three dimensions of organizational justice has taken as dependent variables and two types of purpose of performance appraisal as independent variable, and linked with employee satisfaction. Results of regression model have been shown in Table 3.

We examined a significant positive relationship $(\mathrm{p}<0.01)$ of administrative purpose with distributive and procedural justice. The regression coefficient for both the variables was $45.2 \%$ and $19.4 \%$ respectively. $\mathrm{R} 2$ was calculated as 77.3 percent. These findings confirmed $\mathrm{H} 1$. We also examined a positive significant relationship between the developmental purpose and interactional justice recording a regression coefficient of $32 \%$. R2 was calculated as $34.7 \%$. These findings confirmed $\mathrm{H} 2$. We also examined a significant relationship $(\mathrm{p}<0.01)$ between the employee satisfaction and procedural justice having regression coefficient of $24.9 \%$. R2 indicated $76.4 \%$ variance in procedural justice. These findings confirmed H3. In the last, we examined the relationship between employee satisfaction and organizational justice. The regression coefficient was found significant having a value of $21.2 \%$. These findings confirmed H4.

\section{Discussion}

The aim of this study is to find out the purposes of performance appraisal that are associated with organizational justice. According to Jawahar, (2007) the performance appraisal system success depends on employee's perception of fairness and positive appraisal reaction including employee satisfaction. Conventionally, studies on performance appraisal stressed on the relationship between employee satisfaction and perceived purposes. There is a relationship between developmental purpose and satisfaction with rater (Klein et al., 1987). The results of this study supported (H1) reporting significant positive relationship between administrative purpose of performance appraisal and distributive and procedural justice. It looks credible that when organizations or universities make decisions about salary, fringe benefits, promotion of the employees it produces a positive impression regarding fairness in procedures and its outcomes. These results also supported (H2) that the developmental purpose of performance appraisal has positive and significant relationship with interactional justice.

According to Youngcourt et al. (2007) the administrative and developmental purposes are considered as individual focused. Based on their nature individual focused purposes have strong association with organizational justice. Issues related with employees like hiring, firing, salary are tangible in nature and subsequently influenced employees' daily routine as well as their general behavior in institutions. Therefore, there must be as sound and effective performance appraisal system which is based on justice and ultimately it leads to enhance employee's efficiency and performance. Such system of fairness reduces turnover and absenteeism rate and also creates loyalty and commitment within employees for organization.

Table3: Results of Regression Analysis for Organizational Justice and Employee Satisfaction

\begin{tabular}{|l|l|l|l|l|l|l|}
\hline $\begin{array}{l}\text { Dependent } \\
\text { variables }\end{array}$ & $\begin{array}{l}\text { Independent } \\
\text { variables } \\
\text { purpose }\end{array}$ & Beta & R2 & $\begin{array}{l}\text { Adjusted } \\
\text { R2 }\end{array}$ & significance & F \\
\hline $\begin{array}{l}\text { Administrative } \\
\text { justice }\end{array}$ & 0.452 & 0.773 & 0.713 & 0.000 & 115.955 \\
\hline $\begin{array}{l}\text { Developmental } \\
\text { purpose }\end{array}$ & Procedural justice & 0.194 & & & & 0.000 \\
\hline $\begin{array}{l}\text { Interactional } \\
\text { justice }\end{array}$ & 0.320 & 0.347 & 0.336 & 33.311 \\
\hline Employee & Procedural justice & 0.249 & 0.764 & 0.734 & 0.000 & 245.440 \\
\hline
\end{tabular}




\begin{tabular}{|l|l|l|l|l|l|l|}
\hline $\begin{array}{l}\text { Employee } \\
\text { satisfaction }\end{array}$ & $\begin{array}{l}\text { Organizational } \\
\text { justice }\end{array}$ & 0.212 & & & & \\
\hline
\end{tabular}

Furthermore, these findings indicate that there is significant relationship exist between the two types of justice and the employee satisfaction. (H3) shows that employee satisfaction has positive and significant relationship with procedural justice. $\mathrm{H} 3$ is confirmed as it indicates a strong positive association between employee satisfaction and organizational justice i.e. distributive and procedural justice. These results also oppose previous research owing that employee satisfaction is only linked to distributive justice (Jawahar, 2007). It is because some part of the population of this sample thinks that if the technique used for performance appraisal is unbiased definitely it will enhance the fairness of performance appraisal in organizational purposes such as compensations and promotions.

The (H4) hypothesis is also supported by these results as a positive relationship is established between organizational justice and employee satisfaction. These results have already been confirmed by previous studies e.g.(Jawahar, 2007).

\section{Conclusion}

This study briefly labels the significance of the three components of organizational justice such as interactional, procedural and distributive along with employee satisfaction. Though, performance appraisal usually goes along with perception of fairness and satisfaction. Its execution is important for both managers and employees. The findings of this study lead to some recommendations and suggestions for researchers and scholars that can be illustrated as follows. It is recommended for the new employees i.e. faculty members to be aware of the performance appraisal procedures at the earlier start of their institutional or organizational life. The faculty members should know all about the performance appraisal during the orientation process. This will support them in their evaluation process and subsequent procedures prevail in the institutions. If performance appraisal ensures organizational justice regarding all the three elements of justice then in turn employees i.e. faculty members will be satisfied and will put more strength to advance organizational performance. Organizational justice as whole can also lead to enhance employee satisfaction and resultantly it affects productivity and performance positively. The significant relationship of organizational justice including interactional justice with satisfaction assists the significance of rater' role in employee satisfaction. The findings of this study also identified the importance of fairness and justice for every organization in general and especially for higher education sector i.e. universities in Pakistan. It is worth mentioning that if faculty member's perceived organizational justice in universities regarding performance appraisal definitely they will be satisfied and get motivated to perform better and efficiently. Satisfaction with ratings is also encouraging employees to participate actively and revise their performance according to the demand of the organization. This study shows a positive relationship of organizational justice with employee satisfaction and will assist policy makers to devise such a performance appraisal system for universities which propagate fairness and justice along with satisfaction for progressing towards high job performance of employees.

This study was limited only to public sector universities of Peshawar and its employees i.e. faculty members. Future research should be extended to other regions of the country including private universities and the data should be collected from both the faculty members and administrative staff in order to find out the gap in perceptions of them to analyze its possible effect on such variables. This study is also lacking discussion on informational justice.

\section{References}

Afridi, A. A. (2018). The Role of Organizational Justice in Job Satisfaction and Turnover Intention: A Mediating Role of Trust. Iqra National University, Peshawar.

Al-Zu'bi, H. A. (2010). A study of relationship between organizational justice and job satisfaction. 
International Journal of Business and Management, 5(12), 102.

Armstrong, M., \& Taylor, S. (2014). Armstrong's handbook of human resource management practice: Kogan Page Publishers.

Bakotić, D. (2016). Relationship between job satisfaction and organisational performance. Economic research-Ekonomska istraživanja, 29(1), 118-130.

Bernardin, H. J., \& Wiatrowski, M. (2013). Performance appraisal. Psychology and Policing, 257.

Boswell, W. R., \& Boudreau, J. W. (2000). Employee satisfaction with performance appraisals and appraisers: The role of perceived appraisal use. Human Resource Development Quarterly, 11(3), 283.

Cardador, M. T. (2014). The effects of positive versus negative impact reflection on change in job performance and work-life conflict. Frontiers in psychology, 5, 1370.

Chernyak-Hai, L., \& Tziner, A. (2014). Relationships between counterproductive work behavior, perceived justice and climate, occupational status, and leader-member exchange. Revista de Psicología del Trabajo y de las Organizaciones, 30(1), 1.

Cleveland, J. N., \& Murphy, K. R. (1992). Analyzing performance appraisal as goal-directed behavior. Research in personnel and human resources management, 10(2), 121-185.

Colquitt, J. A. (2001). On the dimensionality of organizational justice: a construct validation of a measure. Journal of applied psychology, 86(3), 386.

De Stobbeleir, K. E., Ashford, S. J., \& Buyens, D. (2011). Self-regulation of creativity at work: The role of feedback-seeking behavior in creative performance. Academy of Management Journal, 54(4), 811-831.

Elamin, A. M., \& Alomaim, N. (2011). Does organizational justice influence job satisfaction and selfperceived performance in Saudi Arabia work environment? International Management Review, $7(1), 38$.

Fernandes, C., \& Awamleh, R. (2006). Impact of organisational justice in an expatriate work environment. Management research news, 29(11), 701-712.

Greenberg, J. (1986). Determinants of perceived fairness of performance evaluations. Journal of applied psychology, 71(2), 340.

Gruman, J. A., \& Saks, A. M. (2011). Performance management and employee engagement. Human Resource Management Review, 21(2), 123-136.

Gunlu, E., Aksarayli, M., \& Şahin Perçin, N. (2010). Job satisfaction and organizational commitment of hotel managers in Turkey. International Journal of Contemporary Hospitality Management, 22(5), 693-717.

Gupta, V., \& Kumar, S. (2012). Impact of performance appraisal justice on employee engagement: a study of Indian professionals. Employee Relations, 35(1), 61-78.

Ikramullah, M., Shah, B., Khan, S., Hassan, F. S. U., \& Zaman, T. (2012). Purposes of performance appraisal system: A perceptual study of civil servants in district Dera Ismail Khan Pakistan. International Journal of Business and Management, 7(3), 142.

Iqbal, N., Ahmad, N., \& Haider, Z. (2013). Impact of Performance Appraisal on Employee's Performance Involving the Moderating Role of Motivation\Oman Chapter of Arabian Journal of Business and Management Review.-2013, Vol. 3, No. 1: Sohar University.

Jawahar, I. (2007). The influence of perceptions of fairness on performance appraisal reactions. Journal of Labor Research, 28(4), 735-754.

Kacmar, K. M., Wayne, S. J., \& Wright, P. M. (1996). Subordinate reactions to the use of impression management tactics and feedback by the supervisor. Journal of Managerial Issues, 35-53. 
Kassing, J. W. (2011). Dissent in organizations: Wiley Online Library.

Katou, A. A., \& Budhwar, P. S. (2010). Causal relationship between HRM policies and organisational performance: Evidence from the Greek manufacturing sector. European management journal, 28(1), 25-39.

Kehoe, R. R., \& Wright, P. M. (2013). The impact of high-performance human resource practices on employees' attitudes and behaviors. Journal of management, 39(2), 366-391.

Kuvaas, B. (2007). Different relationships between perceptions of developmental performance appraisal and work performance. Personnel Review, 36(3), 378-397.

Palaiologos, A., Papazekos, P., \& Panayotopoulou, L. (2011). Organizational justice and employee satisfaction in performance appraisal. Journal of European Industrial Training, 35(8), 826-840.

Peters, M. A. (2013). Managerialism and the neoliberal university: Prospects for new forms of" open management" in higher education. Contemporary Readings in Law and Social Justice, 5(1), 11.

Pooyan, A., \& Eberhardt, B. J. (1989). Correlates of performance appraisal satisfaction among supervisory and nonsupervisory employees. Journal of Business Research, 19(3), 215-226.

Prowse, P., \& Prowse, J. (2010). The dilemma of performance appraisal Business Performance Measurement and Management (pp. 195-206): Springer.

Rowland, C. A., \& Hall, R. D. (2012). Organizational justice and performance: is appraisal fair? EuroMed Journal of Business, 7(3), 280-293.

Selvarajan, T., \& Cloninger, P. A. (2012). Can performance appraisals motivate employees to improve performance? A Mexican study. The International Journal of Human Resource Management, 23(15), 3063-3084.

Shields, J., Brown, M., Kaine, S., Dolle-Samuel, C., North-Samardzic, A., McLean, P., . . . Plimmer, G. (2015). Managing Employee Performance \& Reward: Concepts, Practices, Strategies: Cambridge University Press.

Shrivastava, A., \& Purang, P. (2011). Employee perceptions of performance appraisals: a comparative study on Indian banks. The International Journal of Human Resource Management, 22(03), 632647.

Thurston Jr, P. W., \& McNall, L. (2010). Justice perceptions of performance appraisal practices. Journal of managerial psychology, 25(3), 201-228.

Van Dijk, D., \& Kluger, A. N. (2011). Task type as a moderator of positive/negative feedback effects on motivation and performance: A regulatory focus perspective. Journal of Organizational Behavior, 32(8), 1084-1105.

Warokka, A., Gallato, C. G., Thamendren, A., \& Moorthy, L. (2012). Organizational justice in performance appraisal system and work performance: evidence from an emerging market. Journal of Human Resources Management Research, 2012, 1.

Werner, J. M., \& DeSimone, R. L. (2011). Human resource development: Cengage Learning.

Wright, R. P. (2004). Mapping cognitions to better understand attitudinal and behavioral responses in appraisal research. Journal of Organizational Behavior, 25(3), 339-374.

Youngcourt, S. S., Leiva, P. I., \& Jones, R. G. (2007). Perceived purposes of performance appraisal: Correlates of individual-and position-focused purposes on attitudinal outcomes. Human Resource Development Quarterly, 18(3), 315-343. 
